Acta Universitatis Wratislaviensis • No 4046

Literatura i Kultura Popularna XXVI, Wrocław 2020

https://doi.org/10.19195/0867-7441.26.1

\title{
Jolanta Pasterska
}

ORCID: 0000-0003-0359-0264

Uniwersytet Rzeszowski

\section{Stanisław Uliasz}

ORCID: 0000-0002-1195-3259

Uniwersytet Rzeszowski

\section{Z żałobnej karty. O Profesorze Krzysztofie Dmitruku (1939-2020)}

Profesor doktor habilitowany Krzysztof Dmitruk, znakomity humanista, znawca literatury i kultury polskiej, doskonały nauczyciel akademicki, człowiek niezwykle taktowny, cieszący się uznaniem i sympatią współpracowników i studentów, wpisał się na trwałe w historię polskiej nauki, szczególnie lubelskiej, warszawskiej, krakowskiej, wrocławskiej i rzeszowskiej polonistyki. Odszedł od nas 8 maja 2020 roku.

Profesor Krzysztof Dmitruk urodził się 6 października 1939 roku w Lublinie w rodzinie inteligenckiej. Matka Henryka z Sulińskich i ojciec Stanisław byli pedagogami. W latach 1946-1957 uczęszczał do Szkoły Podstawowej numer 21, a następnie do renomowanego Liceum Ogólnokształcącego im. Stanisława Staszica w Lublinie. Po złożeniu matury w 1957 roku rozpoczął studia w rodzinnym mieście na Wydziale Humanistycznym Uniwersytetu Marii Curie-Skłodowskiej. Już w trakcie studiów opublikował artykuł Dwie miłości w listach Juliusza Stowackiego do matki („A propos” 1959, nr 1). Dyplom magistra filologii polskiej uzyskał na podstawie pracy, napisanej pod kierunkiem prof. dr Janiny Garbaczowskiej, na temat Młoda proza polska lat 1956-1959. Pracę opublikowano w „Annales UMCS” (Lublin 1962).

W dniu 1 sierpnia 1963 roku został asystentem w Katedrze Literatury Polskiej na Uniwersytecie Marii Curie-Skłodowskiej. Od tego momentu datuje się początek drogi naukowej i uniwersyteckiej Profesora. Już w maju 1969 roku uzyskał stopień doktora nauk humanistycznych. Podstawą jego uzyskania była 
rozprawa pod tytułem Twórczość Ludwika Stanisława Licińskiego, ogłoszona drukiem we fragmentach w „Pamiętniku Literackim” (1968, z. 1). Promotorką pracy raz jeszcze była prof. dr Janina Garbaczowska, recenzentami zaś: prof. dr Kazimierz Wyka i prof. dr Władysław Studnicki. Zarówno praca magisterska, jak i rozprawa doktorska dały początek jednemu z późniejszych kręgów zainteresowań Profesora wyznaczanych przez kulturę literacką.

Badania naukowe kontynuował jako adiunkt w Zakładzie Literatury Współczesnej Uniwersytetu Marii Curie-Skłodowskiej. W latach 1973-1975 był kierownikiem Zespołu Naukowego Literatury i Kultury XX Wieku i pełnił obowiązki kierownika zakładu. Następnie 1 sierpnia 1975 roku został pracownikiem naukowym Instytutu Badań Literackich PAN w Warszawie. Nie zerwał jednak kontaktu ze swoimi studentami. Ceniąc sobie pracę dydaktyczną, do 1979 roku prowadził zajęcia w wymiarze połowy etatu na macierzystej uczelni. W Instytucie Badań Literackich w 1981 roku objął funkcję kierownika Pracowni Badań Kultury Literackiej.

W listopadzie 1980 roku habilitował się w Instytucie Badań Literackich PAN na podstawie dysertacji Literatura - społeczeństwo - przestrzeń. Przemiany układu kultury literackiej (Wrocław 1980). Rozprawa otrzymała nagrodę Sekretarza Polskiej Akademii Nauk. Publikacja ta oraz studia Przestrzeń w kulturze literackiej (w: Kultura - komunikacja - literatura. Studia nad XX wiekiem, red. S. Żółkiewski, M. Hopfinger, Wrocław 1976), Wprowadzenie do teorii publiczności literackiej (w: Publiczność literacka, red. S. Żółkiewski, M. Hopfinger, Wrocław 1982), Problemy publiczności literackiej w dawnej Polsce (w: Publiczność literacka i teatralna $w$ dawnej Polsce, red. H. Dziechcińska, Warszawa-Łódź 1985), Galaktyki kultury. (Publiczność literacka między żywym i zapisanym stowem) (w: Kultura żywego stowa w dawnej Polsce, red. H. Dziechcińska, Warszawa 1989), Kultura literacka (w: Stownik literatury staropolskiej. Średniowiecze, Renesans, Barok, red. T. Michałowska, Wrocław 1990), jak również liczne szczegółowe opracowania, hasła słownikowe, artykuły naukowe aż po „profesorską” książkę Współczesne polskie koncepcje kultury (Warszawa 1990) stały się cenionymi kompendiami wiedzy na temat kultury literackiej. Profesor Krzysztof Dmitruk zaprezentował w nich wyniki wieloletnich prac badawczych prowadzonych nad kulturą i literaturą popularną, wypracował metody badania i opisu kultury literackiej, charakteryzował fazy jej rozwoju, stawiał diagnozy, wskazywał na źródła zbiorowej świadomości narodowej, a także wykazywał zainteresowanie folklorem i kulturą regionalną. W tym okresie uczestniczył również w pracach Komisji do spraw Badania Życia Literackiego w Polsce, działającej przy Komitecie Nauk o Literaturze Polskiej PAN. W ramach umów międzynarodowych Instytutu Badań Literackich PAN współpracował z grupą badaczy zajmujących się problematyką kultury społecznej. Brał także udział $\mathrm{w}$ organizowaniu badań komparatystycznych koordynowanych przez Słowacką Akademię Nauk. W roku 1980 uczestniczył w II Krauss-Colloquium w Berlinie. Efektem tych naukowych poszukiwań była rozprawa Die Situation der literarischen Komunikation (w: Geschichte und 
Funktion der Literaturgeschichtsschreibung. Sitzungsberichte der Akademie der Wissenschaften der DDR: Gesellschaftswissenschaften, 1982, $\mathrm{nr}$ 2/G).

Rok później, 1 października 1981 roku, został powołany na stanowisko docenta. W latach 1981-1989 był członkiem Komitetu Nauk o Literaturze Polskiej, w ramach którego kierował pracami Komisji Wiedzy o Kulturze Literackiej.

Z pełnienia funkcji kierownika Pracowni Badań Kultury Literackiej zrezygnował 1 maja 1987 roku i przeniósł się do Pracowni Literatury Oświecenia. Zainteresowanie literaturą i kulturą doby oświecenia towarzyszyło Profesorowi Dmitrukowi od początków Jego kariery. Oprócz wspomnianych już znakomitych prac z zakresu kultury literackiej dawnej Polski do dorobku naukowego dołączył szczegółowe prace poświęcone Józefowi Wybickiemu: Józef Wybicki (w: Pisarze polskiego oświecenia, t. 2, red. T. Kostkiewiczowa, Z. Goliński, Warszawa 1994), Droga do autobiografii. O „Ż̇yciu moim” i korespondencji Józefa Wybickiego (1747-1822) (w: Literatura, historia, dziedzictwo. Prace ofiarowane Profesor Teresie Kostkiewiczowej, red. T. Chachulski i A. Grześkowiak-Krwawicz, Warszawa 2005) oraz Ignacemu Krasickiemu: O sztuce pisarskiej Krasickiego (w: Ignacy Krasicki. Nowe spojrzenia, red. Z. Goliński, T. Kostkiewiczowa, K. Stasiewicz, Warszawa 2001). Ponadto spisał studia o charakterze ogólnym, dotyczące epoki oświecenia, między innymi: Publiczność poludnia XVIII wieku (w: Kultura literacka XVIII wieku w Polsce. Studia i szkice, red. T. Kostkiewiczowa, Wrocław 1992), Oświecenie - archipelagi wspólnot („Wiek Oświecenia” 1998, nr 14), Wokót teorii i historii mecenatu (w: Z dziejów mecenatu kulturalnego w Polsce, Warszawa 1999), Oświecenie - konteksty zmiany kulturowej („Wiek Oświecenia” 2002, nr 17).

Przez wiele lat uczestniczył w pracach zespołu Koordynacyjnego Problemu Węzłowego 11.1 i Centralnego Programu Badań Podstawowych 08.05 „Polska kultura narodowa, jej tendencje rozwojowe i percepcja”. Pełnił funkcję zastępcy redaktora naczelnego Encyklopedii kultury polskiej XX wieku. Był członkiem Polskiego Towarzystwa Semiotycznego i Polskiego Towarzystwa Badań nad Wiekiem XVIII oraz członkiem Komitetu Nauk o Literaturze Polskiej Akademii Nauk.

Stanowisko profesora nadzwyczajnego w Instytucie Badań Literackich PAN objął w 1992 roku, następnie 15 października 1997 roku uzyskał tytuł profesora zwyczajnego.

Profesor Krzysztof Dmitruk czynnie włączał się w życie akademickie, prezentując efekty swoich badań na ogólnopolskich i międzynarodowych konferencjach naukowych organizowanych między innymi przez Uniwersytet Marii Curie-Skłodowskiej, Instytut Badań Literackich, Uniwersytet Wrocławski czy Uniwersytet Rzeszowski. Jako referent brał także udział w wielu konferencjach Polskiej Akademii Nauk, między innymi w XIII Konferencji Teoretycznoliterackiej (luty 1973), sesji naukowej „Życie literackie w Polsce w okresie 1863-1973” (październik 1974), sesji „Polska popularna kultura artystyczna” (styczeń 1975), sesji Komitetu Nauk o Literaturze - „Nowe problemy metodologiczne literaturoznawstwa” (kwiecień 1986), konferencjach „Literatura i kultura” (grudzień 1980), „Publiczność literacka 
i teatralna w dawnej Polsce” (luty 1983), „Semiotyka kultury literackiej” (listopad 1984), „Kultura żywego słowa w dawnej Polsce” (wrzesień 1985), „Nowe zjawiska w badaniach literackich” (listopad 1986), „Problemy procesu historycznoliterackiego” (marzec 1990), „Piśmiennictwo - systemy kontroli — obiegi alternatywne” (grudzień 1990), „Literatura i instytucje w dawnej Polsce” (marzec 1991), „Zjazd Polonistów. Wiedza o literaturze i edukacja” (maj 1995), „Geografia literacka polskiego Oświecenia” (październik 1996), „Co to jest Oświecenie?” (październik 2000) oraz „Ignacy Krasicki 1735-1801. Pisarz i środowisko” (maj 2001). Był ponadto aktywnym uczestnikiem konferencji organizowanych przez Towarzystwo Badań nad Wiekiem XVIII. W listopadzie 2009 roku był współorganizatorem sympozjum i panelu dyskusyjnego poświęconego Jerzemu Grotowskiemu — „W stronę źródeł, rytuałów, przedstawień. O twórczości Jerzego Grotowskiego".

Za osiągnięcia naukowe został wyróżniony wieloma nagrodami; najważniejsze z nich to: nagroda specjalna „Życia Literackiego” za referat $Z$ problematyki młodej prozy polskiej lat 1956-1959, wygłoszony podczas X Ogólnopolskiego Zjazdu Młodych Polonistów (Kraków 1962) i Nagroda Sekretarza Polskiej Akademii Nauk za książkę Literatura - społeczeństwo - przestrzeń (Wrocław 1980).

Poświęcając się pracy naukowej, Profesor Krzysztof Dmitruk nigdy nie zapomniał o swoim pedagogicznym powołaniu. Wysoko cenił sobie zajęcia ze studentami i młodymi pracownikami nauki. Był dla nas prawdziwym autorytetem, czego dowodem jest wypromowanie ponad stu magistrów filologii polskiej. Było to możliwe dzięki podjęciu zajęć dydaktycznych w ramach drugiego etatu w Instytucie Filologii Polskiej ówczesnej Wyższej Szkoły Pedagogicznej w Rzeszowie, gdzie w latach 1992-1994 prowadził seminaria magisterskie oraz wykłady monograficzne. Prace te kontynuował także w Instytucie Filologii Polskiej Państwowej Wyższej Szkoły Pedagogicznej imienia Komisji Edukacji Narodowej w Krakowie (lata 1994-1996). W 2002 roku Profesor Dmitruk został pracownikiem naukowym Uniwersytetu Rzeszowskiego i członkiem Zakładu Teorii i Antropologii Literatury w Instytucie Filologii Polskiej. Był też członkiem Rady Redakcyjnej czasopisma „Literatura i Kultura Popularna” (w ramach serii „Acta Universitatis Wratislaviensis”). Jego nazwisko pojawiało się obok takich znawców, jak Maria Bujnicka, Janusz Dunin, Jacek Kolbuszewski, Erazm Kuźma, Anna Martuszewska, Roch Sulima czy Tadeusz Żabski.

Profesor Krzysztof Dmitruk miał swój znaczący wkład w rozwój czasopisma „Tematy i Konteksty”. W latach 2010-2018 uczestniczył w pracach redakcji jako jej aktywny członek, a od 2019 roku wspierał pismo jako przedstawiciel Rady Naukowej. W prace redakcji zawsze wnosił niezmącony spokój, takt i dobry humor, inicjował inspirujące dyskusje, życzliwie aprobował redakcyjne inicjatywy, był prawdziwym mentorem tego grona, zawsze gotowym do udzielenia mądrego wsparcia i światłej rady.

W 2011 roku współpracownicy z Uniwersytetu Rzeszowskiego oraz innych ośrodków akademickich w kraju przygotowali monografię zbiorową Obszary kultury. Ksiega ofiarowana Profesorowi Krzysztofowi Dmitrukowi w 70. rocznice urodzin (red. J. Pasterska, S. Uliasz, Rzeszów 2011). 
W okresie wieloletniej pracy dydaktyczno-wychowawczej Profesor Dmitruk prowadził ćwiczenia i konwersatoria z poetyki, stylistyki i wersyfikacji oraz analizy utworów literackich, a następnie wykłady kursowe z zagadnień kultury języka, metodologii badań literackich, literatury polskiej XX wieku, teorii literatury, arcydzieł literatury światowej, antropologii kultury i literatury oraz problemów historii kultury. Prowadził ponadto otwarte wykłady powszechne i monograficzne z wybranych problemów antropologii literatury. Niezmiennie od lat dużym zainteresowaniem cieszyły się prowadzone przez Profesora seminaria magisterskie i doktoranckie, w których trakcie studenci i słuchacze podejmowali badania nad literaturą i kulturą XX wieku, w tym kulturą regionu, antropologią kultury i teorią przekładu. Efektami swoich badań oraz swoją wiedzą chętnie dzielił się ze studentami i młodymi pracownikami nauki, czego widocznym potwierdzeniem byli słuchacze ustawiający się pod drzwiami gabinetu w godzinach (często przedłużanych) konsultacji Profesora. Wiele wysiłku włożył w starania o rozwój młodego pokolenia badaczy. W trakcie swojej kariery naukowej Krzysztof Dmitruk sporządził kilkadziesiąt recenzji prac doktorskich i habilitacyjnych, opinii i wniosków o nadanie tytułów profesorskich, recenzji wydawniczych, a także ekspertyz dla Komitetu Badań Naukowych. Przy życzliwym wsparciu Profesora Dmitruka powstała w Instytucie Filologii Polskiej Uniwersytetu Rzeszowskiego Pracownia Badań i Dokumentacji Kultury Literackiej, w której prowadzone są studia nad kulturą regionu oraz literaturą i kulturą na obczyźnie.

Profesor Krzysztof Dmitruk angażował się w prace nad badaniami kultury popularnej i antropologii kultury. Do uznanych rozpraw z tego zakresu należą: $H i$ storia i melancholia (Polityka w ,, Trędowatej” Heleny Mniszek) (w: Z problemów aksjologii literatury i kultury popularnej. Prace ofiarowane Józefowi Nowakowskiemu, red. S. Uliasz, Rzeszów 1996), Metodologiczne problemy badań geografii kultury. Europa i Polska XVIII wieku (w: O dialogu kultur wspólnot kresowych, red. S. Uliasz, Rzeszów 1998), Portret i autoportret władzy. Cenzura w „Narkomanach" Ireneusza Iredyńskiego (w: Pejzaże kultury. Prace ofiarowane Profesorowi Jackowi Kolbuszewskiemu w 65. rocznice Jego urodzin, red. W. Dynak, M. Ursel, Wrocław 2005), Przekład w kulturze literackiej polskiego Oświecenia. Prowizorium dokumentacyjne (w: Literatura i jej konteksty. Prace ofiarowane profesorowi Czesławowi Kłakowi, red. J. Rusin, K. Maciąg, Rzeszów 2005). Jest też autorem haseł słownikowych „Pisarz” i „Geografia literacka” w Stowniku literatury polskiej XX wieku (red. A. Brodzka et al., Wrocław 1992) oraz „Stereotyp”, „Kultura masowa”, „Kultura popularna”, „Obiegi literatury” w Stowniku literatury popularnej (red. T. Żabski, Wrocław 1997). Jest również współredaktorem książki W stronę źródet twórczości Jerzego Grotowskiego (Rzeszów 2009), wydanej z okazji Roku Jerzego Grotowskiego.

Wspominane wcześniej autorskie książki, rozprawy i artykuły, wreszcie wystąpienia na sesjach naukowych wyraźnie się zazębiały i dopełniały, stały się ważnym elementem wzbogacającym dorobek historii literatury i kultury literackiej. Wyznaczały też kręgi zainteresowań uczonego, które tworzyły: socjologia i an- 
tropologia literatury, problemy teorii i historii kultury literackiej oraz teoria i historia literatury popularnej. Z perspektywy minionego czasu wyraźnie widać, że łączy je jeszcze jedno - niezwykła erudycja i wyczucie piękna. Krzysztof Dmitruk jako wybitny znawca kultury jest i pozostanie jednocześnie jej znakomitym orędownikiem. To humanista, który nie tylko zajmował się zawodowo kulturą, literaturą czy językiem, człowiek dbający o wartości ludzkie, umiejący dostrzec urodę świata i życia. Wielu z nas, Jego uczniów, zawdzięcza Profesorowi Dmitrukowi fascynację kulturą minojską, cykladzką czy Dalekim Wschodem. Jego barwne, prowadzone piękną polszczyzną opowieści dotyczące rozwoju kultur i ich zmienności lub etnicznej różnorodności zawsze przyciągały rzesze słuchaczy. Był ciekawym nieznanych krain, nastawionym na nowe odkrycia czy to kreteńskiej Matali, czy to japońskiego Kioto uczonym, niestrudzenie poszukującym w tych miejscach śladów współistnienia wielu kultur. To jednocześnie człowiek, który z oddaniem służył swojemu środowisku, skromny, niosący zawsze pomoc, zainteresowany Drugim/Innym, jego odmiennością i wartością tego, co stworzył. Był humanistą, który przez całe życie poszukiwał źródeł kultury, kontemplował jej piękno w każdym wymiarze. Zapamiętamy Profesora jako wybitnego uczonego i dobrego człowieka. 